\title{
AREA PROTECTION IN VIEWS OF ITS RESIDENTS
}

\author{
Pavlína Maříková ${ }^{1}$, Irena Herová ${ }^{2}$
}

Received 20 June 2010; Accepted 10 December 2010

Abstract: In Central Europe, there is practically no natural area, which would not be touched by man. Not even recently protected natural areas are pieces of virgin nature. Therefore, it would be reasonable to ask, whether the conservation and protection of the current state justifies restrictions of development for groups of inhabitants living in these areas. The next question to answer is whether it is realistic to presume that an area, which is for some reason protected, and where some restrictions are laid, is automatically disadvantaged in terms of development of society. This article reviews literature on impacts of area protection in the Czech Republic and abroad. The relation of area protection and socio-economical development is analyzed through opinions of inhabitants of protected localities. Further, the communication between authorities and inhabitants is evaluated. The goal is to show examples of good practice and to find factors necessary for positive adoption of area protection.

Key words: landscape, nature protection, human activities, negotiation

Souhrn: Ve střední Evropě v podstatě neexistuje území, které by bylo bez zásahu člověka. Ani chráněná území nejsou původní nedotknutá př́roda. Proto je otázka, zda ochrana právě současného stavu přírody opravňuje k omezování rozvoje společnosti žijící ve vybraných území. Další otázkou je, jaká míra ochrany, která by měla bránit prrípadnému rozvoji je obhajitelná a zda ochrana území skutečně rozvoj limituje. Dopředu se předpokládá, že území, které je z nějakého důvodu chráněno, tedy jsou zde dána nějaká omezení, je znevýhodněno z hlediska rozvoje společnosti. Článek přináší shrnutí dostupné literatury o dopadech ochrany území v České republice i v zahraničí. Vztah oblasti ochrany území a sociálně-ekonomického rozvoje je analyzován prostřednictvím názorů obyvatel těchto chráněných lokalit. Dále je také hodnocena komunikace mezi úřady a obyvateli. Cílem článku je ukázat prííklady dobré praxe a najít faktory nezbytné pro pozitivní přijetí ochrany území.

Klíčová slova: krajina, ochrana prírody, lidská činnost, vyjednávání

\section{Introduction}

Man influences the landscape since a long time. People change the environment according to their needs - for agricultural purposes, building villages and cities. Centuries ago, a harmonic structure of the landscape was essentially a non-planned bi-product of agrarian life. (Dejmal, 2000) However, with industrialization, this landscape has been gradually destroyed. Various

\footnotetext{
${ }^{1}$ Ing. Pavlína Maříková, Department of Humanities, Faculty of Economy and Management, Czech University of Life Science Prague, Kamýcká 129, 16521 Praha-Suchdol; e-mail marikova@pef.czu.cz

2 Ing. Irena Herová, Department of Humanities, Faculty of Economy and Management, Czech University of Life Science Prague, Kamýcká 129, 16521 Praha-Suchdol; e-mail herova@pef.czu.cz
} 
environmentally conscious initiatives and efforts to protect the environment did not rise until the $20^{\text {th }}$ century. Today, the landscape is at least partially protected and damaged areas are gradually being restored.

Protection of landscape can be done in many ways and for many different reasons. Area can be protected for its natural or cultural heritage, or for economical purposes. From the sociological point of view, these cases are similar - the life of inhabitants is being affected in a way by some limitations. The core of the problem is an emerging conflict between protection and socioeconomic development. This is a very up-to date problem.

From the sociological point of view these issues have not been well researched yet. The relation of an individual to the environment has been analyzed only marginally e.g. by Beck and BeckGernsheim (2002). Librová (2010) explains the reasons: "The need and effort to solve environmental problems and to protect nature is historically new phenomenon. It is not possible to approach it equipped only with the old values and motivations." Environmentalists and environmental scientists also start showing interest in social problems related to environmental protection. The connection of these two fields gives rise to Social Ecology as described by Murray Bookchin (1980). Further, M. M. Bell (2004) engages in Environmental Sociology and P. W. Taylor (1986) in Environmental Ethics.

This review is, however, not focused on the relation of individuals to their living environment. We are rather interested in the relationships of a group (mostly inhabitants of a certain area one or several municipalities) and the society, which set some limitations for this group in order to protect the environment. We analyze how the members of the group deal with these limitations and what are the impact of the limitations on development of the area.

In the Czech Republic, people perceive the preparation of area protection because of their future use mainly negatively. They point out the negative impacts on socio-economic development of the municipalities and on their inhabitants. In this review, we bring an overview of examples of area protection in the Czech Republic and other European countries and their impact on the development. We seek the answer to the question: "Does area protection always limit development?" and show examples of good practices and factors necessary for positive adoption of area protection.

\section{Goals and Methods}

This review was created as a part of the project "Multidisciplinary evaluation of area protection impacts in important water management localities in CR", which will in detail map the selected localities and analyze the impacts of area protection on social and economical development. Neither Czech nor European literature brings data on the same situation - protection of area because of planned water management structure (the situation in China is not comparable because of a different political regime). Therefore, studies with the common topic "area protection and its socio-economical impact" were reviewed independently from the reasons for this protection. The most common is the protection of natural or cultural heritage. We summarize and analyze the socio-economical impact of area protection and the methods of communication with public in these cases.

Furthermore, we present some preliminary data from the above mentioned study. We carried out 60 semi-standardized interviews with mayor of municipalities located close to areas suitable for water accumulation, and which therefore lay in the protected area. We compare the preliminary outputs from these interviews to the findings of other authors.

\section{Landscape protection in CR and its image in the society}

A territory could be protected because of its nature, its cultural or architectural heritage. Historically, any area protection is considered a hindrance of socio-economic development. Relationship between nature protection and municipal development in the context of regional development was analyzed by the team of Institute of System Biology and Ecology of the Academy of Sciences of the Czech Republic in their comparative empirical study. (Kušová, Těšitel et al., 2005) The assumption that nature protection is a limiting factor in socio-economic development of municipalities was to be verified or disproved in this study. The study was 
carried out in three different Protected Landscape Areas (PLA), that are also recognized internationally as biosphere reserves: Šumava National Park (NP), Třeboňsko PLA and Křivoklátsko PLA. They differ from each other both in their natural parameters and historically formed socio-economic conditions. Three groups of villages in each PLA were compared: municipalities lying within PLA, on the border and up to $20 \mathrm{~km}$ away from PLA and outside from this radius (Kušová, Těšitel, Bartoš, 2008) The three regions were analyzed based on three different sources of data: basic socio-demographic characteristics, type of land use and semi standardized interviews. The results showed that villages inside PLA are not less developed than villages outside. People living in PLAs are closely embedded in their natural surroundings, they appreciate healthy environment, and they do not feel to be handicapped in socio-economic sense.

Result of the same project called "Participative management of protected areas - a key to minimize conflict between biodiversity protection and socio-economic development of local communities" was the realization that areas could be protected through restrictions but also through compensation. (Kušová, Těšitel, Bartoš, 2008b) Large scale protected areas are the topic of interest of science not only for their unique ecosystems and species, which are necessary to protect, but also as a source of knowledge about interaction between nature and society, which could lead to successful sustainable coexistence. According to the law 114/1992 coll. on nature and landscape protection the representatives of protected areas have efficient restrictive tools for nature protection. However, if the inhabitants are only limited (in use of land, building, mobility) they perceive the protection negatively even thought they agree with the purpose of the protection per se. Non-restrictive tools of protection should therefore be included as a compensation of possible slow or hindered development. Four functions of nature protection areas were demonstrated on the example of three above mentioned biosphere reserves: biological diversity protection, scientific and professional research, education and training and support of sustainable development. Biosphere reserves could fulfill all these four functions if all interest groups in the area interconnect and cooperate. If inhabitants of a protected area have the possibility to participate in the management of the protected area they better understand the reasons for restrictions and they can better identify with them. Informed inhabitants know very well that their natural environment is good not only for their health but also conceals potential for sustainable tourism as s source of local development. European funds are also available for support of societies in protected areas. Such regions are eligible for special funds which cannot be applied by other regions.

Content analysis of articles is regional press related to the 3 biosphere reserves in 5 years period $(1998$ - 2004) was performed with the hypothesis that "the press reflects the expected interest of the public in concrete problems, reacts to everyday problems of life in concrete community and is always monitored by interested institutions." (Kušová, Těšitel, Bartoš, 2005b) The aim of the study was to find out the relationship between nature protection and communal development. The Šumava NP was mentioned five times more often than other two PLAs and the most common problem was the communication on the NP authority with some municipalities. Municipalities cannot be understood as a homogenous group. Some of them understand the necessity of the nature protection and are able to use it for development of tourist services, other, usually with high rate of unemployment, struggle to be excluded from the Park area or encourage the transfer of their area into a lower category of protection. Reasons of antagonism presented in press could be summarized as follows: compensations and grants, historical assets of land, land resources, bark beetle occurrence, and method of management. A turn of management and conflict solutions in Šumava NP was expected with each change of minister of environment and exchange of director of NP. Despite of problems, many examples of good and functional cooperation between NP and communities are mentioned in the analysis: educational and enlightenment activities, cooperation in application for subsidies that help to improve infrastructure and municipal facilities for tourism. In five years, the rhetoric of articles changed to positive sense, which indicates improving cooperation between NP administrative and municipalities in region.

Relationships between municipalities and Křivoklátsko PLA were presented without serious conflict; both share interest in development of tourism. Cooperation was mentioned in positive cases, e. g. educational and enlightenment activities, cooperation in application for subsidies, 
building of sewage system, museum of nature, castle reconstruction, etc. The declaration of Natura 2000 - bird area proceeds without any problems.

Also relationships between municipalities and Třeboňsko PLA sounded in regional press similar; no conflict. If some discrepancies occurred they concerned functioning of municipalities and every winter problems with maintenance of roads (in PLA is forbidden to use salt). Unlike in Krivoklátsko region, the press evidenced problems of regional producers and entrepreneurs (fish farming, gravel exploitation, deep-well water pumping, spa and tourism). The examples show that problems do not necessarily have to be between institution of nature protection and the whole community, but it could be affair of one private entrepreneur. The press referred about many good examples of cooperation in the region.

It is possible to view the outcome of the content analysis in historical consequences. In Krrivoklátsko and Třeboňsko both systems - PLAs and communities got used to and adjusted to each other (Křivoklátsko was established in 1977 and Třeboňsko in 1979). The Šumava region was only declared as a National park in 1991. With regard to the relatively short time of existence of this NP, and to stricter protection of nature, some controversies are evident. The municipalities in the region struggle for financial contributions to their budgets and for reduction of unemployment. From the change of connotation of articles in regional press to more positive it is evident that authorities of both systems realize that the main role of area protection is not only keeping of unique nature heritage but also support of potential for sustainable and quality life in protected localities. All involved actors agree with important role of tourism in limited extend for sustainable development of the localities. The nature protection seems to be the source of economic development based on local potential.

Pools (Frantál, 2008, Frantál, Kunc, Cetkovský, Kučera, 2008) regarding public support of using so called "clean sources of energy" - concretely power from wind plants - showed that people support the idea. They support construction of wind plants, they are willing to pay slightly higher fees, and they don't mind to spend holiday time in locality with wind plants. The support ends if wind-power plant should be installed in their place of residence (fear of noise, change of landscape's relief and other negative impact). This phenomena is called NIMBY (Not-In-MyBackyard) and describes the fact that people agree with any good idea in general level but are against in the frame of own locality. The opinion is not much influenced by age, gender or level of education of respondents.

The weekly Respekt reports on the Ministry of Environment of CR aim to declare part of PLA Krrivoklátsko national park (Pavlíček, 2008). Representatives of administration of PLA Krrivoklátsko organized meeting with mayors of municipalities that could be affected and together with administrations of České Švýcarsko NP explained them what regime they could expect. The head of PLA Krrivoklátsko was invited by one mayor on meeting with inhabitants to the pub and he explained the problematic to about fifty local visitors. From several interviews with inhabitant is clear that they agree with protection of area but in their concrete case they are afraid to loose their free access to forest and possibility to gain wood for heating.

\section{Landscape protection abroad}

Exceptionally strong conflict against protection of area occurred in Finland in Karvia region in 1997. (Hiedanpää, 2002) Four landowners went on hunger strike in protest against the proposed Natura 2000 Network. Almost $70 \%$ of the area is surfaced with bog and marshland. Local landowners have drained and afforested their land for many years. Livelihood of inhabitants depends mostly from primary production - dairy and forestry. The level of education of inhabitants is mainly basic and the number of farms in Karvia is the fifth-highest in the whole country. In the frame of establishing the Natura 2000 Network, previously protected area should have been broadened and the protection would mean some restrictions in forestry. Farmers were organized in professional associations. The one week hunger strike ended with the visit of the minister of environment and the minister of agriculture and forestry and nearly a half of the areas were withdrawn from the Natura proposal. The outcome of the analysis of the conflict is that one-way top-down communication in the case is not enough. Landowners want to be actively involved in the planning process. 
The importance of participation is also emphasized in the comparative study on approach to protection of area in two biosphere reserves in Switzerland and Ukraine - UNESCO sites. (Wallner, Bauer, Hunziker, 2007).

Following typology of 7 types of participation was defined (Pimbert, Pretty, 1997):

1. Passive participation

2. Participation in information-giving

3. Participation by consultation

4. Participation for material incentives

5. Functional participation

6. Interactive participation

7. Self-mobilization

Types 1 - 4 do not involve any activity of inhabitants and represent the situation when protected area is established by the top-down method by statutory rules without consultations with local communities. Types 5 - 7 enable active participations of local communities in the process.

"In order to achieve sustainable conservation with long-term economic and environmental success, it is essential to value the people's ideas and knowledge and to give them the possibilities to make decisions independent from external agencies,, (Pimbert, Pretty, 1997). It is necessary to realize that protection of the area always brings some restrictions into life of inhabitants that are very difficult to express in money.

The local inhabitants rather connect protected area with restrictions than with advantages of potential of development and source of livelihood. The UNESCO Biosphere Entlebuch, Switzerland was established from initiative of municipal council in the effort to make better economic situation of inhabitants in protected area. The proposal was approved by the vast majority of inhabitants in public pool. (type 6 or 7 ). The Carpathian Biosphere Reserve, Ukraine was created according to a Decree of the President of Ukraine on the base of state reserve (top-down method, passive participation, type 1). Qualitative research was carried out in three villages in each reservation. The 38 in-depth interviews (14 in Switzerland and 24 in Ukraine) were processed with intention to look into and understand local problems. The Swiss respondents were chosen on information meetings according to the level of their activity in discussions. Because in the Ukrainian region no meetings were held, the respondents were chosen gradually on the base of previous interviews according to methodology of qualitative research. Therefore the number of interviews had to be higher.

The question, whether the foundation of biosphere reserve in their area is good was not answered with yes or no. Therefore the conclusion of this analysis is not a clear statement whether the method (bottom-up or top-down) influenced the perception and support of protected area by its inhabitants. They often wrongly connect the area protection with some problems that are not its consequence.

The Swiss appreciated higher tourism and possibility of local development and the protection of present state of landscape. On the other hand, they are afraid that the farming of land will be regulated more strictly than in the past.

In Ukraine, people mentioned very specific fears: difficult approach to cheap wood for heating, impossibility of farming on their land (state does not have money to pay off compensations), fear of wild animals (negative experience from 1930s and 1940s), they are afraid of too great power of reservation's authorities. People appreciate the stopping of intensive timber harvesting and therefore protection against floods. The key categories for evaluation of the reservation are economic situation in the region, history of nature protection, balance between power and competences.

Natural environment is not protected only for keeping nice life conditions for local people. The aim is the protection of important natural assets for preservation of biodiversity and for future generation. Therefore it is important to know the opinion of the whole society, not only of the local people, on who should participate on the protection of nature. (Zachrisson, 2008) To what extend, people mean, is it necessary to involve local people on the decision making? The research tested the hypothesis in three levels: dependence on resources, understanding 
and trust. The aim was to find out whether, in people's opinion, the protected area should be managed solely by local volunteers (self-management) or the power and responsibility should be shared by locals and representatives of the state (NP or government) (co-management). This hypothesis was developed from the dispute whether protection of nature is predominantly responsibility of the state or of the local community, which uses local resources. Following hypotheses were tested:

Hypothesis 1: Local resources will be best managed by people, who are dependent on them or who live in the locality.

Hypothesis 2: People, who are informed why and by what means an area is protected willmore likely agree with self/co-management, regardless wherethey live.

Hypothesis 3: People with low trust in others, in politicians and in democracy are more likely to agree with self-management, while those with high trust in democracy are for co- or state management of protected areas.

Based on the quantitative research of two samples of 8,868 respondents following conclusions were made: People from the cities were more often for higher level of participation of local people (self-management), while people from the countryside preferred co-management. The opposite result was expected. However, the division the population into rural and town is too simplistic, therefore it is not possible to generalize these results. Hypothesis 1 had been based on the presumption that employees of the primary sector are dependent on natural resources; e.g. forestry workers are dependent on tree felling. The results of the research, however, showed that they more often prefer self-management and vice versa - those who promote self-management are more often not dependent on natural resources. In agreement with the hypothesis 2, proponents of self-protectionism thought that there were too many protected areas and/or the protection was too strict. Generally the Swedish public wishes to change the rules of nature protection to certain extend - mostly on the structure of management. They find it necessary to have feedback, whether the protection fulfills its goals. Also hypothesis 3 proved right; people in favor of self-management have often low trust in others and in politicians, while co-management is more often favored by those who have trust in democracy, politicians and other people in general.

A German team studied the area of Val Grande, valley in the Italian Alps (Höchtl, Lehringer, Konold, 2005). 20 years ago, an area of 12 thousands ha was pronounced a national park and thus the largest biosphere reserve in Italy and in the Alps. In the core of the park (950 ha of land), all agricultural, forestry and shepherding activities were forbidden, although the land had been farmed in the past. The research analyzed ecological and social impact based on local and regional documents and data from archives. Opinions of local inhabitants as well as tourists and other visitors on current situation and the future of the area were also collected and analyzed. During the period of 3 years, surveys were carried out focusing on the life in villages, traditional agricultural produce, landscape and nature. Every year, results were first summarized and then used as a basis for the questionnaire for next year. The collected data showed that the national park has rather psychological effect. Both inhabitants of municipalities and visitors of the park expressed regret over the wasting of human work (fields and pastures) and loss of cultural heritage. Local inhabitants feared spreading of fires to their homes from uncontrolled growing forests, were loosing ties to the area as to their home. Tourists valued the wild nature but missed tourist infrastructure. Many respondents connected the park with virgin nature, although only 2 decades ago it was farming area. Favorable scenario for future development of the area would be nature protection, which would enable preservation of the ecosystem and its studying but also the existence of local farming. Tourist would like to buy local products ( $72 \%$ respondents). $62 \%$ respondents wish a combination of environmentally friendly tourism with local farming, forestry and shepherding. The members of the local community should be able to participate on the decision making in the protected area.

The concept of ecodevelopment (Collin, 1990) was asserted in the biosphere reserve Cevennes in France. This area was pronounced national park in 1970 and a biosphere reserve in 1985. Many unique plant species can be found here on a relatively small area. However, the area had been populated already in ancient times and it was desirable to protect also the traditional agricultural architecture from the $17^{\text {th }}$ century build from local materials (granite, limestone, dry chestnuts etc.). The reservation should therefore protect nature as well as architectural and 
cultural heritage. The representatives of the reservation had to find a compromise between the demands of local people, who wanted to farm the land, and the interests of natural protection. The dialogue between these interest groups began with the project of an ecomuseum. Together they planned an educational program that would connect theory with practice and focus on ecological as well as historical issues. In this case the compromise was found, in other aspects, however, there are still some disagreements - for example on the regulations of game hunting. Throughout the time the reservation representatives could make connections with the representatives of different interest groups (agricultural, hunting, tourist and educational) and reveal some more intimate reasons for conflicts and solve these.

The main conclusion of the reviewed studies is that inhabitants of protected areas connect the protection with limitations and restrictions rather than seeing it as a potential for development and advantage for themselves. (Fiallo, Jacobson, 1995, Müller-Böker, Kollmair, 2000, or Ormsby, Kaplin, 2005) However, participation of local inhabitants and the bottom-up initiatives can contribute to better acceptance of the protection.

\section{Area protection for water management purposes in the Czech Republic}

Global climatic changes are influencing the whole planet and can in the future have different consequences in different regions. Territorial studies of the Czech Republic predict alternating dry and flood periods as one of the possibilities. It is therefore necessary to prepare for the lack of water as well as its overabundance. For this reason, the Plan of the main catchment (Plán hlavních povodí České republiky) basins from 2006 was prepared together with the list of more than 200 localities suitable for the construction of water dams - so called localities for accumulation of surface waters ${ }^{3}$. The dams would not only serve to accumulate water in dry periods but also as a protection from frequent floods. This list includes, for the most part, localities, which had already been indicated in the Water Management Plan from $1975^{4}$.

When in 1989 the political regime changed from directive socialistic to democratic, the citizens expected that all restrictions laid down by the past regime would be removed. The social climate was described for example by Možný (1991). However, according to the current government, it is in the interest of future generations to continue protection of the selected areas as a means of water management and flood protection. The current building law does not permit building structures for transport and technical infrastructure of national and international importance and structures and facilities serving for industrial, energetic, agricultural or mining purposes, which could disrupt geological and morphological characteristics of these areas. This limitation also concerns landfills. Housing and infrastructure of local importance are permitted.

The above mentioned law prepared in 2006 awoke a great displeasure from the public. NGOs and mayors of municipalities located in prospective selected areas were expressing the most explicit disagreement. They pointed out that such limitations would affect the municipalities and stop their further development. The purpose and reasons for future construction of dams were also criticized and the possible climatic scenarios were questioned. The opponents had been so strong that they stopped the adoption of the bill listing selected localities and the solution of the problem was postponed by several years.

In 2007 the study "Socio-economic analysis of area protection in prospective localities suitable for accumulation of surface waters" was published ${ }^{5}$. It analyses the impact of area protection in these localities. The study consists of statistical analysis of all municipalities, whose territories

\footnotetext{
${ }^{3}$ The plan of the main catchment basins of the Czech Republic is a long term concept in water management with the focus on the six-year period 2007 - 2012. It was created by the Ministry for Agriculture in cooperation with the Ministry for Environment and concerned offices of central and regional administration. The plan is a part of continuous conceptual water management guaranteed by the state. It was anchored in the Czech body of laws according to the guidelines of the European Parliament and Commission 2000/60/ES from 23.10.2000, which establishes the framework for the activities of the Community in water management and water policy.

${ }^{4}$ Directive Water Management Plan was in 1975 created as an update of the State Water Management Plan from 1953. It is (with several additions and small changes) a foundation source in water management up to now. It serves as a directive plan for water management purposes in all sectors of national economy and for landscape planning.

${ }_{5}$ Jílková, J., Květoň, V., Slavíková, L. (2007). Socioekonomická analýza územního hájení výhledových lokalit vhodných pro akumulaci povrchových vod, IEEP, www.ieep.cz
} 
totally or partly overlap with the areas proposed in 2006, and compares the development in "old" localities (protected since 1988) and the "new" ones (protected only since 2006). Several case studies are also included. Further goal of the study was to propose methodology for eventual actualization of the above mentioned list of localities and for accomplishment of consensus between local actors and state organs.

The study seeks the answers to the following questions: Did the selection of protected areas have in the past any (negative) influence on their development? If yes, in what aspects? If not, what are the reasons for this? What are the key socio-economic criteria for the evaluation of development of municipalities located in prospective protected areas? What is the historical experience with protected areas in individual municipalities?

Based on the database of socio-economic indicators, statistical correlations and possible time links were sought in the group of municipalities under protection. The municipalities were split into size categories with up to 500 , up to 1,000 , up to 3,000 and more than 3,000 inhabitants. It was of interest whether the development during past 19 years varied (for example in intensity of migration or housing development, etc.). After the comparison of socio-economic indicators of municipalities that have been under protection for almost 20 years (394 municipalities) and municipalities till now not affected (204), the authors of the study observed no significant differences in most analyzed indicators. This means that the development in both groups of municipalities is influenced by other factors, for example the problems of the period of economy transformation. Further, comparative analysis of 6 triples of municipalities with similar socioeconomic characteristic was carried out (always 1 municipality in protected and 2 in not protected areas). Consequently, case studies were carried out in the 6 municipalities in protected areas. They show that the inhabitants were only informed about the protection when it implied a concrete limitation for the municipality for example in the form of building restriction. There is very low awareness among the mayors about the water management purposes of the protection valid after 1988. The analyses show that the development of municipalities in protected localities was little influenced by the protection. Moreover, they show a great variability in the awareness level - from the awareness of strict but seemingly unsubstantiated building restriction to zero awareness and uninfluenced development.

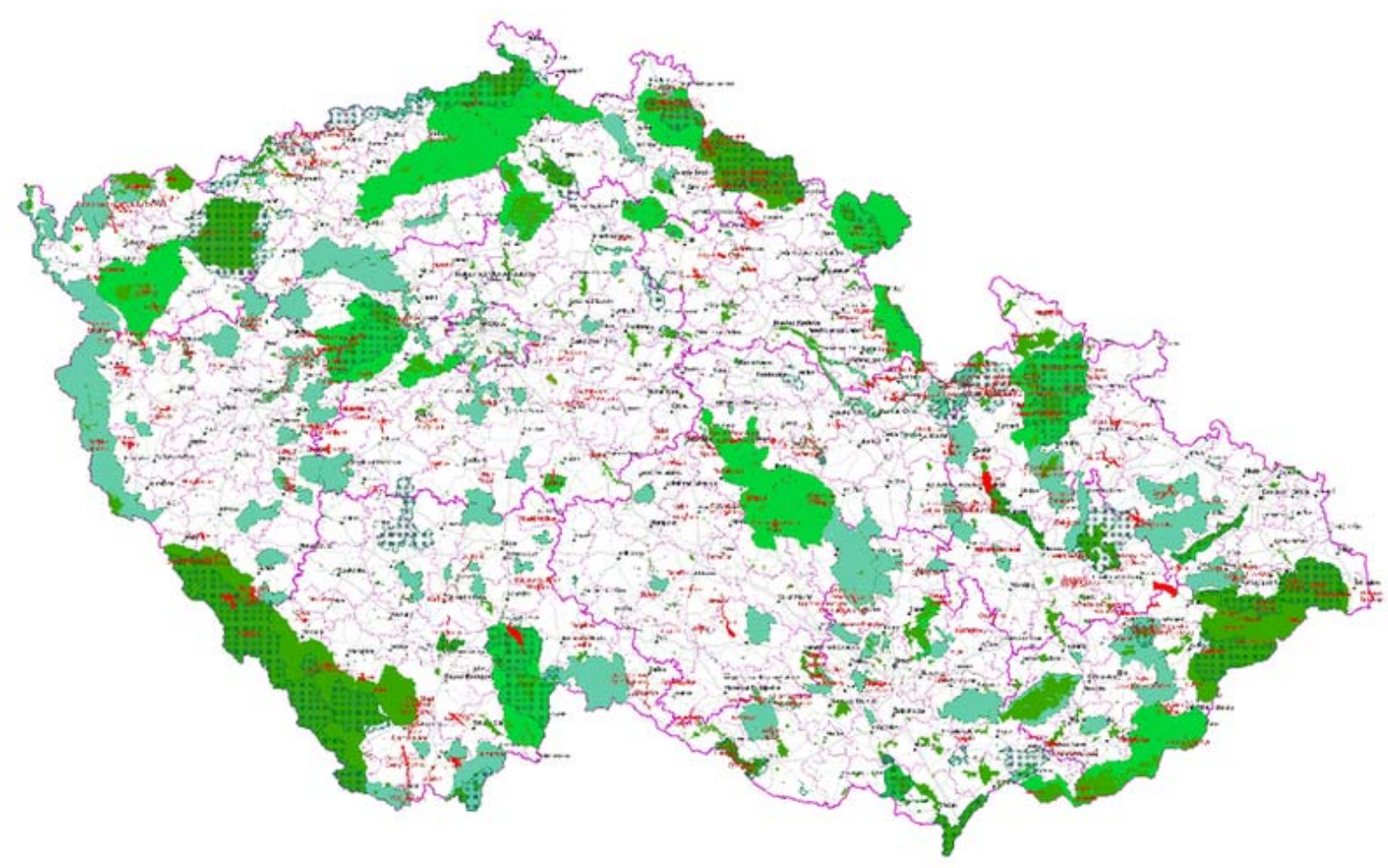

Fig 1. Map of Localities suitable for accumulation of surface waters Legend: green areas = different types of protected environment areas, red areas = planed water dams 
We were interested what the general knowledge on this issue is. An analysis of general public awareness ${ }^{6}$ revealed that most articles published in printed and electronic media during past 4 years (2005-2009) concerned one case only - the dam Nové Herrminovy, and the public resistance to its by government approved construction. Some other texts comment on the parliamentary debate on the Plan of main catchment basins or mention protests in other localities. These texts are mostly published on the websites of opponents (for example www.stopprehrade.cz) and environmental NGOs (Duha, Arnika, Veronica, Cello, Zelený kruh, Greenpeace, etc.) or other interest groups (water sports associations). Arguments explaining the choice of the concrete localities, their protection and their future use from the representatives of government or the catchments management are found only exceptionally. Most official statements only observe that the government passed the above mentioned list and that the protests are continuing.

The general public has joined the discussions on various web sites as well as during the conference Water in the Landscape and various panel discussions with professionals on local level. Almost hundred comments were sent by layman and representatives of municipalities in the frame of open discussion to the parliament. An open letter delivered to the government of CR to the reading of the bill on the Plan of main catchment basins in 2006 was signed by 52 representatives of towns and municipalities, two associations of municipalities and 46 associations and organizations and tens of individuals. 20 affiliates of universities and academics have sent an open statement to the government and thousands of citizens have signed diverse petitions.

These voices have been in several ways successful; although there was no broader discussion between professionals and public, the government have, based on the comments and arguments of professionals, made certain changes in the Plan and postponed the finalization of the list of localities. Changes were also made for the already accepted dam Nové Heřminovy. It will be smaller than originally planed, which will protect part of the houses from forced demolition. New forms of protection against floods and retention of water in the environment are taken into consideration; for example changes in agriculture.

Although the problems with planned accumulation of surface waters immediately concern 200 places in CR only, there are at the same time about 600 municipalities, whose area overlaps these localities. A couple more numbers for better understanding of the reality: over 1 million people live in these localities, if dams were build in all of them in their maximal size, almost 5000 housing facilities, which at the moment give shelter to about 15,000 inhabitants, and thousands of other buildings often of recreational character used by further thousands of people would be flooded. Thus the problem does not only concern the permanent residents of the potentially endangered municipalities but also large group of vacationers and tourists, water sportsmen and other people, who make use of these localities. We must not forget the owners and leaseholders of forests and fields. The solution of their ownership rights is very complicated and would alone be topic for a further article.

Therefore the problems of surface water management as a means of water accumulation and flood protection can be considered as problems of the whole society and can be perceived from sociological point of view.

\section{Discussion}

Various examples from the Czech Republic as well as from other European countries have shown that inhabitants of protected areas are not always willing to respect the rules connected with the program of protection. Many people look at these rules and restrictions that come from "the top" as something the public cannot influence. In some situations, it is possible to prevent the changes (example from Finland). However, often an open and communicative approach of authorities brings a change into public opinion.

The problem of misunderstanding nature protection in the Czech Republic is based mostly on an incorrect behavior of the authorities toward public. Protection of the environment is planed on national or regional level but inhabitants of discussed areas are not informed or consulted.

\footnotetext{
${ }^{6}$ Carried out by the members of the Sociological Laboratory at the University of Life Sciences Prague in 2009
} 
There is a minimum chance for public to influence the decisions, which can cause negative approach of the inhabitants.

Our preliminary results show that the municipalities in the localities protected for prospective accumulation of surface waters develop independently from their position close to a prospective water dam. The representatives of these towns are often not even informed about the fact. Those who have some information, try to prevent getting their town involved by such actions as writing petitions. Some inhabitants know that the area of their municipality overlaps with the area protected by the Water Management Plan from 1975 but hold the plan for out of date. Some mayors of municipalities learned about the protection when they wanted to change the municipal plan in order to enable construction of some technical infrastructure. The localities suitable for accumulation of surface waters are often at the same time protected natural areas. The representatives of municipalities located in such areas mostly accept necessity to consult the managers of the natural reserves before any change in the municipal plan. But they react negatively when realizing that the area is protected by other authorities as well. Such reaction correlates with examples from the literature where inhabitants conform to some long-term limitations but react negatively to a new change or limitation if they are not informed properly and could not participate in the decision about it.

Most of the time, people are not against area protection as such, they protest when it touches their lives and interests. Top-down approach always brings more complication and resentment. People need the feeling that area protection will bring them more advantages than limitations. If it is not possible to reach such state, compensations should be the solution.

\section{Conclusion}

Area protection in localities of accumulation of surface waters has one common characteristic with protection in natural reservations - it is essential that the selected areas stay preserved in current state and remain protected from different negative influences (transport infrastructure, chemical production, landfills etc.). At the same time, present quality of life of their inhabitants should not decrease.

There is, however, one substantial difference; localities of accumulation of surface waters can in the future become the ground for construction of dams or other water management structures. It is today hard to say with what probability and when this will happen. The first dam has already been accepted for realization. This dam, although built in its small variant, will flood over 50 houses and will force their inhabitants to move.

The necessity to of resettlement is not the main problem, according to the opponents of the plan. Their reproach concerns the purpose and sense for construction of dams, protection of nature and other technical issues connected with protection from floods.

The reviewed studies as well as our preliminary results show that area protection does not have to hinder development. However, following three point have to be paid attention to, so that the inhabitants accept the protection of their area.

- INFORMATION - acquiring of information by lay public is made difficult predominantly through complicated terminology. Representatives of general public usually search information about a concrete locality and only in an aftermath realizes that it is included in a list of hundreds of other places. Basic summary of the issue can be found at the websites of the opponents (www.stopprehrade.cz), and on the websites of various ecological organizations. The document "Plan of main catchment basins" can be found at the websites of the Ministry of Agriculture in whose competence water management is. Further official information can be given by individual catchment authorities (Labe, Vltava, Ohře, Morava, Odra) but clear and for laymen understandable official information is missing. Nobody has answers to the question of "common people", whether their house can be flooded or how the Plan concerns their village. This uncertainty creates fear and reproach.

- COMMUNICATION - responsible organs and institutions did not show (with some exceptions) readiness to communicate with public during the preparation of the Plan. There was communication on higher level only - directly with municipality authorities; and one way (questions were not answered, information without the possibility to discuss). As shown in 
the case study of J. Jílková, many mayors were in 2007 still not aware that their municipality is included in chosen locality. Lack of communication is the second aspect that contributes to negative approach of public. As above mentioned researches and studies showed, communication and sound argumentation can change the attitude of public toward protection.

- PARTICIPATION of public in decision making is the most important moment, which influences the opinions and attitudes of public. The public only had two chances to participate in the preparation of the bill, which includes the Plan of main catchment basins - during the debate on the bill in May and in October 2006. In both cases, little less than hundred of persons, municipalities and organization used this possibility. Their comments were accepted, explained or declined. Those who did not make use of this possibility (did not know about it) could not participate on the decision making. The plan was accepted in May 2007. The Plans of areas and localities were prepared in the following year. Also here, there was the possibility to comment. However, not everyone knew about this possibility. Furthermore, not everyone is able to understand and comment large technical document. The public would need some simpler and clearer possibility such as municipal referendum, petition or panel discussion. The lack of possibilities of influencing of decisions on local level strengthens the feeling that common people cannot change the decisions of the state authorities and have to follow the directive pressure of the state.

Librová (2010), however, sees the possibilities of an individual optimistic: "notwithstanding all restrictions in democratic system, an individual can become the moving force of partial environmentally favorable changes. Thanks to the reintegrational affection of man, i.e. when he joins a group of similar-minded individuals (elective affinity group - Maffesoli (1996), he is able to positively change local environmental situation, limit the interference in nature on local level and even influence some small steps of legislature or political reparation."

The example of decision making in the case of area protection in localities of accumulation of surface water shows, which social problems can occur. However, the construction of power plants, highway or other structures that significantly change the landscape can lead to similar situations. Any interventions will be perceived negatively as long as the decision about them is made from the top and the inhabitants do not have trust in the politicians and professionals, do not have enough information and most importantly are not involved in the decision making. Only then they will stop feeling that since the times of socialism nothing has changed and they themselves cannot change the march of events around them. Then we will be able to speak about open modern society, which responsibly decides about its own future.

This process could be also supported by following the suggestions determined by the Aarhus Convention. According to the Convention, the public should act as a partner of the administration office, should have right to be given intelligible information about environment, to take a part in making decisions, and right to access to justice. If these rules take place in the common life, the negative public approach could be changed.

\section{Acknowledgement}

Pieces of knowledge introduced in this paper resulted from the solution of the research project of the Ministry of Agriculture of the Czech Republic No. QH81170 "Multidisciplinary evaluation of impacts of special territorial protection for hydrological important areas in CR".

\section{References}

[1] Aarhus Convention, source: http://www.unece.org/env/pp/documents/cep43e.pdf

[2] Beck, U. \& Beck-Gernsheim, E. (2002). Individualization. London: Sage

[3] Bell, M. M. (2004). An Invitation to Environmental Sociology. Thousand Oaks: Pine Forge Press

[4] Bookchin, M. (1980). Toward an Ecological Society. Montreal: Black Rose 
[5] Collin, G. (1990). Rural Society and Protected Area: Which Dialogue? The Case Study of Cevennes National Park and Biosphere Reserve (France). Landscape and Urban Planning, 19(2), 173-180. Doi:10.1016/0169-2046(90)90052-4.

[6] Dejmal, I. (2000). Co s evropskou kulturní krajinou na konci 20. století? In.: Kulturní krajina aneb proč ji chránit? Praha: Ministerstvo životního prostředí ČR.

[7] Fiallo, E. A. \& Jacobson, S.K. (1995). Local communities and protected areas: attitudes of rural residents towards conservation and Machalilla National Park Ecuador. Environmental Conservation 22 (3), 241-249. Doi:10.1017/S037689290001064X.

[8] Frantál, B. (2008). Výzkum veřejného mínění o problematice využívání čistých zdrojů energie v obcích Rakov, Horní Netčice, Býškovice, Malhotice a Opatovice. [Výzkumná zpráva]. Brno: Ústav geoniky AV ČR.

[9] Frantál, B., Kunc, J., Cetkovský, S., Kučera, P. (2008). Rozvoj větrné energetiky a cestovní ruch: hrozba či přiležitost? In: Kunc, J. (ed.): Sborník př́ispěvků ze semináře „Mezinárodní rok planety Země“. Brno: Ekonomicko-správní fakulta Masarykovy univerzity.

[10] Hiedanpää, J. (2002). European-wide conservation versus local well-being: the reception of the Natura 2000 Reserve Network in Karvia, SW-Finland, Landscape and Urban Planning 61(2-4), 113-123, Doi:10.1016/S0169-2046(02)00106-8.

[11] Höchtl, F., Lehringer, S. \& Konold, W. (2005). "Wilderness": what it means when it becomes a reality - a case study from the southwestern Alps, Landscape and Urban Planning 70)1-2), 85-95. Doi:10.1016/j.landurbplan.2003.10.006.

[12] Kušová, D., Těšitel, J., Bartoš, M. (2008). Biosphere reserves - An attempt to form sustainable landscapes. A case study of three biosphere reserves in the Czech Republic, Landscape and Urban Planning 84 (1), 38-51. Doi:10.1016/j.landurbplan.2007.06.006.

[13] Kušová, D., Těšitel, J., Matějka, K., Bartoš, M. (2005) Nature Protection and Socioeconomic Development in Selected Protected Landscape Areas. Ekológia (Bratislava), Vol. 24, Suplement 1/2005, 109-123.

[14] Kušová, D., Těšitel, J., Bartoš, M. (2008b). Biosphere reserves - learning sites of sustainable development?, Silva Gabreta, vol. 14(3), 221-234.

[15] Kušová, D., Těšitel, J., Bartoš, M. (2005b) The media image of the relationship between nature protection and socio-economic development in selected Protected Landscape Areas. Silva Gabreta 11(2-3), 123-133.

[16] Librová H. (2010) Individualisation from an Environmental Perspective: How Sociological Framing Alter Outlooks and Generates Questions, Czech Sociological Review 46(1): 125152.

[17] Maffesoli, M. (1996) The Time of the Tribes: The Decline of Individualism in Mass Society. London: Sage

[18] Možný, I. (1991). Proč tak snadno...: některé rodinné důvody sametové revoluce: sociologický esej. Praha: Sociologické nakladatelství.

[19] Müller-Böker, U. \& Kollmair, M. (2000). Livelihood strategies and local perceptions of a new nature conservation project in Nepal. Mountain Research and Development 20(4), 324-331.

[20] Ormsby, A. \& Kaplin, B.A., (2005). A framework for understanding community resident perceptions of Masoala National Park, Madagascar. Environmental Conservation 32 (2), 156-164. Doi:10.1017/S0376892905002146.

[21] Pavlíček, T. (2008). Jsme na tom závislí, Respekt 44/2008.

[22] Pimbert, M.L. \& Pretty, J.N. (1997). Parks, people and professionals: putting "participation" into protected-area management. In: Ghimire, K.B. \& Pimbert, M.P. (Eds.), Social Change and Conservation. Environmental Politics and Impacts of National Parks and Protected Areas (pp. 297-330). London: Earthscan. 
[23] Taylor, P. W. (1986). Respekt for Nature: A Theory of Environmental Ethics. Princeton: Princeton University Press.

[24] Wallner, A., Bauer, N. \& Hunziker, M. (2007). Perceptions and evaluations of biosphere reserves by local residents in Switzerland and Ukraine. Landscape and Urban Planning 83(2-3), 104-114. Doi:10.1016/j.landurbplan.2007.03.006.

[25] Zachrisson, A. (2008). Who should manage protected areas in the Swedish mountain region? A survey approach to co-management. Journal of Environmental Management 87(1), 154-164, Doi:10.1016/j.jenvman.2007.01.010. 